\title{
The predominantly facultative nature of epibiosis: experimental and observational evidence*
}

\author{
Martin Wahl**, Olaf Mark \\ Zoologisches Institut, University of Kiel, 24098 Kiel, Germany
}

\begin{abstract}
Epibiosis is a spatially close association between 2 or more organisms belonging to the same or different species. Through direct and indirect interactions, this association has major effects on the species involved and on community dynamics. When the effects are predominantly beneficial for epibiont and basibiont, coevolution can be expected to lead to associational specificity. Circumstantial evidence, however, suggests that many epibionts are non-specific substratum-generalists. In this article, we investigate the commonness of specificity in epibiotic associations. In a first approach, we investigated the in situ recruitment preferences of potential epibionts when choosing between artificial and living substrata. After exposure for $3 \mathrm{wk}$ in early summer, an early successional community had established, comprising cyanobacteria, diatoms, sessile colonial ciliates and red algae. All species recruited on almost all substrata available. However, artificial substrata were usually preferred over living surfaces. Consequently, the species studied are classified as facultative epibionts. An analysis of a list of over 2000 epibiotic associations corroborated these results: the majority of described 'epibionts' are not basibiont-specific and generally occur on non-living substrata as well. Also, basibiont species usually bear more than 1 epibiont species. Relative to each other, epibionts and basibionts are characterised by a typical set of life history traits. We conclude that specific and obligate epibionts are rare. Their scarcity is discussed in view of multilevel antifouling defences and presumptive evolutionary transitions from epibiosis towards endoparasitism or endosymbiosis.
\end{abstract}

KEY WORDS: Recruitment · Facultative epibionts - Epibiosis - Parasitism - Symbiosis · Artificial substrata $\cdot$ Living substrata

\section{INTRODUCTION}

Due to the physical characteristics of water as compared to air, in the aquatic environment-even for consumers-a sessile mode of life is possible (food vector water) and often favourable (reduced risks of dislodgement, Wahl 1997). While there are also thousands of species of terrestrial epibionts (algae, lichens, mosses, some phanerogames), the great majority of these associations is limited to humid climates and to the plant kingdom, for epi- as well as basibionts (Barkman 1958, Benzing 1989, Kress 1989, Luettge 1989, Bruteig 1994j. In the aquatic realm, tens of thousands

\footnotetext{
-Accompanying this article are supplementary Internet files at www.int-res.com/journals/suppl/ listing aquatic epibioses

- Present address: Dept. Natural Resources \& Conservation, Univ. of Namibia. E-mail: mwahl@unam.na
}

of species with representatives from most of the marine phyla have adopted this mode of life for at least 1 ontogenetic phase: many bacteria, many protozoa, many diatoms, most macroalgae, all sponges, most cnidarians, many molluscs (bivalves, gastropods), some rotifers, most bryozoans, most phoronids, many brachiopods, many tube-building polychaetes, some echinoderms, a few crustaceans (e.g. cirripedia), some hemichordates, and all ascidians.

In many shallow, hard-bottom habitats, sessile life forms dominate the benthic community in terms of number of individuals and species. A decoupling of feeding medium (water) and attachment medium (substratum) may make suitable settlement area a limiting factor in marine habitats. The colonisation pressure exerted by meroplanktonic dispersal stages can be intense on submerged surfaces (e.g. Davis et al. 1989) Recruitment onto living surfaces leads to epibioses. 
Thousands of 'epibiotic associations' comprising a substrate organism (basibiont) and one or several attached species (epibionts) have been reported from marine and freshwater habitats (see supplementary Internet files). When settling on a substratum, numerous colonisers have been reported to cue on surface properties like rugosity, wettability or colour, on biogenic signals like the exudates of earlier colonisers or of the basibiont, and/or on environmental conditions like irradiation levels or microhydrodynamics (e.g. Boudreau et al. 1990, Henschel \& Cook 1990, Roberts et al. 1991, Morse 1992, Pawlik \& Butman 1993, Kjelleberg \& Holmstrom 1994). The presence of epibionts modifies numerous interactions between basibiont and biotic or abiotic components of the system (consumption, drag, etc., Wahl \& Hay 1995, Wahl et al. 1997, Laudien \& Wahl 1999). Epibiosis may negatively affect basibionts by increasing weight and friction, by decreasing flexibility, by shading basibionts from light and access to dissolved molecules, or by inflicting 'shared doom'. On the other hand, basibionts may benefit from the presence of epibionts due to effects like optical and chemical camouflage, reduced friction, protection against desiccation and harmful irradiation, or associational defence. As hard substratum often is limited, epibiosis provides the epibiont with this valuable resource. When epibiosis-related effects are neutral or positive for a basibiont species and beneficial for the epibiont species, selection should favour the evolution of active attraction by the basibiont and/or settlement specificity of the epibiont species. In view of the widespread occurrence of aquatic epibiosis and the innumerable examples of cueing behaviour described, we should expect an important proportion of specificity in epibiotic associations. In contrast, our observations underwater suggested that most 'epibionts' exhibit low substratum specificity and may be found on a huge variety of substrata.

In order to address the question of the commonness of specific epibiotic association, we experimentally assessed recruitment patterns on artificial and living substrata. The emerging pattern of substratum specificity was subsequently compared to the pattern provided by an analysis of over 2000 epibioses described in the literature, communicated by colleagues or observed by ourselves.

Additionally, we tried to extract from this material major life history traits characterising epibionts and basibionts, respectively.

\section{METHODS}

Experiments were carried out in the Baltic Sea off Kiel (Germany, $54^{\circ} 28^{\prime} \mathrm{N}, 10^{\circ} 13^{\prime} \mathrm{E}, 1 \mathrm{~km}$ off shore, depth $5 \mathrm{~m}$, April 26 until June 8, 1994). In a restricted area of $<1$ ha, planktonic recruitment onto artificial and living substrata within or near pre-existing or SCUBAbuilt organismic microhabitats was assessed. Microhabitats of Zostera marina (Spermatophyta) and Laminaria saccharina (Phaeophyta) already existed, separated by sandy areas. Into these sandy patches, stands of Delesseria sanguinea (Rhodophyta) and of Fucus serratus (Phaeophyta) were transplanted with their substratum (stones) from neighbouring areas. Thus, within a small and physically homogeneous area, 4 microhabitats (diameter 1 to $5 \mathrm{~m}$ ) came to coexist: $Z$. marina, F. serratus, L. saccharina, D. sanguinea. Average plant densities were $8,10,12$ and $30 \mathrm{~m}^{-2}$, respectively. Biovolumes in plant stands were comparable.

Small $(1.5 \times 4.5 \mathrm{~cm})$ plastic strips (Dymo ${ }^{\text {TM }}$ ) were employed as artificial settlement substrata. Numbered individually and coded for microhabitat, they were exposed within the respective microhabitats. Ten replicated substrata per microhabitat were designated for the analysis of protozoan and multicellular fouling, 6 for the analysis of diatom fouling. The substrata were either attached to stakes planted between the plants of a given microhabitat, or - in the case of Laminaria saccharina and Fucus serratus--tethered directly to the stiff stipes or 'branches'. We firmly attached artificial substrata with their back side to or close to the stiffest plant parts in order to minimise or prevent contact with other plant surfaces. In an attempt to ensure independence of replicates, the distance between artificial substrata was always greater then 3 times their lengths (Hurlbert 1984). On retrieval of the artificial substrata, plant parts of an age equivalent to the duration of exposure (ca $6 \mathrm{wk}, 5$ replicates) were collected from the same microhabitats. Age estimates were based on in situ monitoring of growth rates. To avoid contamination, living and artificial substrata were sealed individually in sterile containers while underwater.

In the lab, the density of diatoms was assessed by autofluorescence microscopy (wavelength of excitation: $546 \mathrm{~nm}$ ) on a circular area (diameter $215 \mathrm{~m}$ ) picked at random on each surface $(6$ replicates per microhabitat). Another 10 replicates per microhabitat were dyed with Bengal Red (Sigma R4507) and the central $1 \mathrm{~cm}^{2}$ of artificial substrata and plant surfaces was examined for ciliates and multicellular colonisers under a stereomicroscope. For Corallinacea and Ceramium rubrum coverage was estimated to the nearest $10 \%$.

Data were paired (artificial and living substrata in a given microhabitat) and, due to typically different recruitment densities of different species, variances were heterogeneous. Consequently, rank-transformed recruitment densities were statistically analysed by a Wilcoxon Paired-sign test. The level of significance was $5 \%$. 
The correlative analysis of the nature of epibiosis is based on the interpretation of ca 2000 epibiotic associations which stem from our own observations, personal communications of colleagues and a literature review (see supplementary Internet files). These case studies were used to extract the most common features of epibionts and basibionts and the specificity of the associations.

\section{RESULTS}

\section{Substratum preferences}

During the $6 \mathrm{wk}$ exposure, a typical early successional assemblage developed: cyanobacteria (Oscillatoria sp., not analysed), diatoms (Cocconeis sp., Licmophora sp., Navicula sp.), sessile ciliates (Ascineta sp., Folliculina sp., Vorticella sp., Zoothamnium sp.), and red algae (Ceramium rubrum and an unidentified corallinacean). All species (colonisers and microhabitat-constituting organisms) will hereafter be referred to by their generic names.

All coloniser species settled in almost all microhabitats (Fig. 1), the only exception being Ceramium missing in the Laminaria patch.

Within any microhabitat, settlers generally preferred artificial substratum over living surfaces of macroorganisms (Table 1, Fig. 1, $\mathrm{p}<0.001, \mathrm{n}=35$ [8 species in 4 microhabitats plus 1 species in 3 microhabitats]). The only significant exceptions were the preferences of the ciliates Acineta for Zostera and Folliculina for
Delesseria surfaces compared to the corresponding artificial substrata. However, even these latter coloniser species in the remaining microhabitats settled more densely on artificial substrata. Overall, when choosing between artificial and living substrata in 35 coloniser-by-microhabitat combinations, recruits significantly preferred living surfaces in 2 combinations, and significantly preferred artificial substrata in 17 combinations. The clearest discriminative recruitment was exhibited by the corallinacean alga, which invariably avoided living surfaces, and by the diatom Cocconeis, which on average preferred artificial substrata by a factor exceeding 100. Colonisers affected least by the nature of the substratum were the protozoans Zoothamnium and Vorticella, preferring artificial substrata by a factor 4 , on average. In general, Laminaria and Fucus thalli seemed more repellent, i.e. featuring reduced specific abundances, than Delesseria and Zostera surfaces (see Fig. 1 and Table 1). This impression may not be analysed statistically, though, because microhabitat types were not truly replicated.

\section{Characteristics of epibiotic associations}

The analysis of 2005 epibiotic associations yielded the following trends: 15 phyla of the plant and animal kingdoms were represented sufficiently often in the list to be included in the analysis (Fig. 2). Among these, 11 provided more than 50 described epibiotic or basibiotic species per phylum. Ten of the phyla included both epibiotic species and basibiotic species. The ratio
Fig. 1 Recruitment onto artificial versus living substrata (S.). Calculated as the $\log$ of the ratio of $a b$ solute mean abundances on the 2 substrata per species and microhabitat. Negative values: preference for living substrata. Positive values: preference for artificial substrata. Absence on living substrata while present on artificial substrata gives 'infinite' preference for the latter (cut here arbitrarily at 10000-fold preference). White and dark columns stand for significant preferrences for artificial and for living substratum, respectively. Grey columns indicate non-significant trends. The general preference for artificial substrata is significant: $p=0.0001$

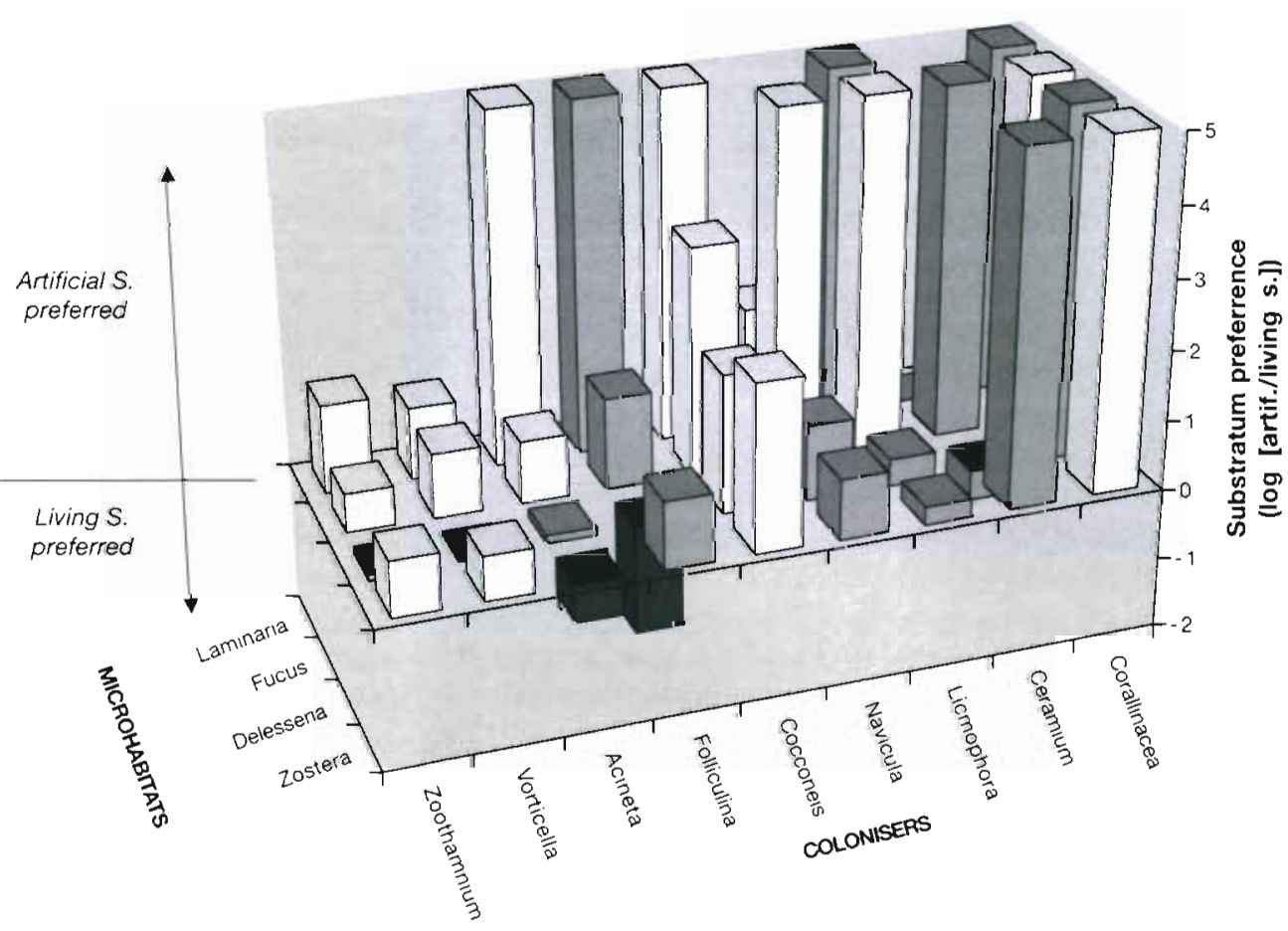




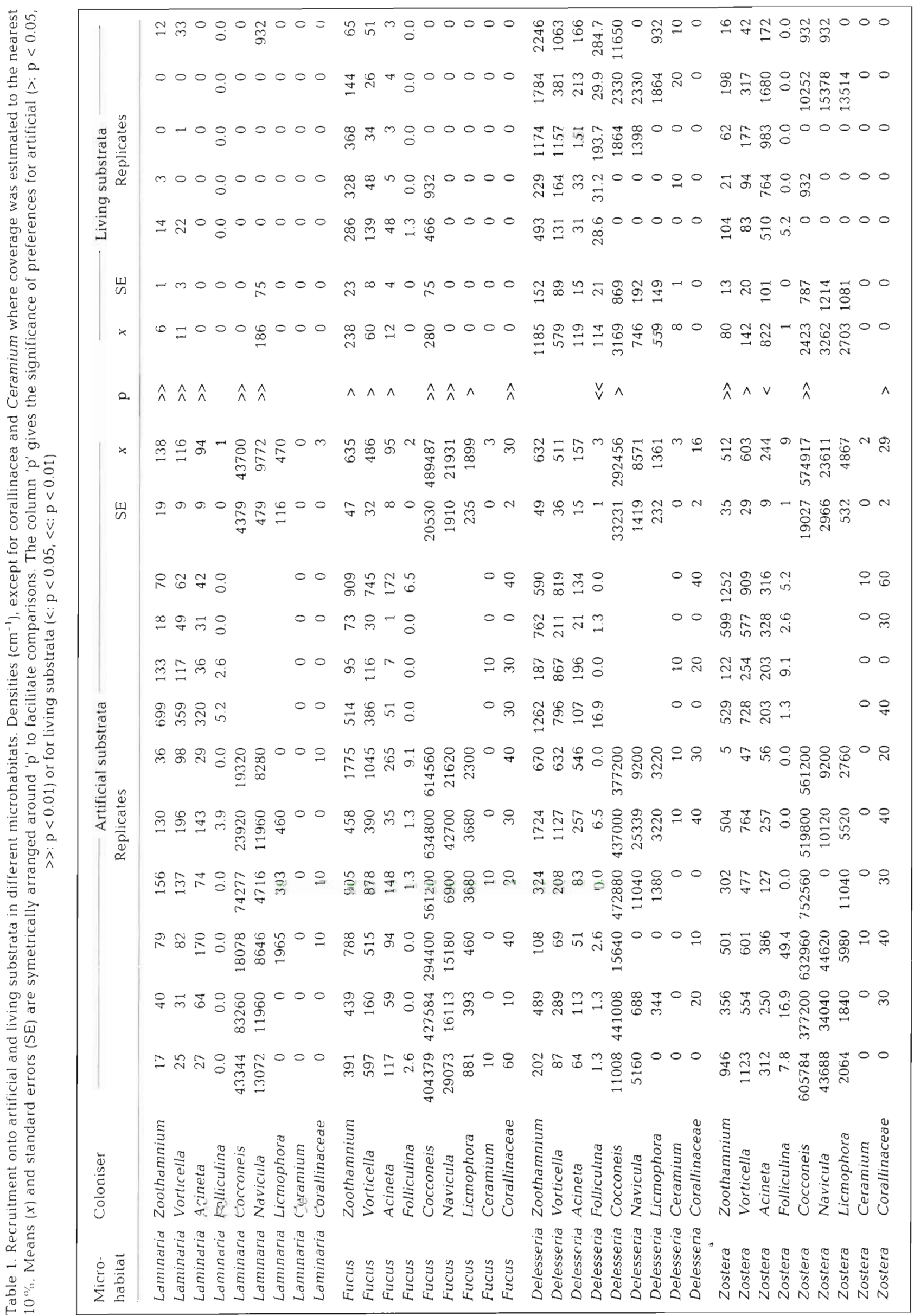


Fig. 2. Numbers of epibiotic and basibiotic species in the phyla most commonly represented in the list of epibiotic associations. The phyla are arranged by decreasing intraphylum ratio epibiotic species/basibiotic species. Abbreviations: $\mathrm{BRYO}=$ Bryozoa, $\mathrm{CHLOR}=$ Chlorophyta, $\mathrm{CNID}=$ Cnidaria, CRUST $=$ Crustacea, DIAT = Diatomeae, ECHIN = Echinodermata, MOLL $=$ Mollusca, PHAEO = Phaeophyta, POLY = Polychaeta, PORIF $=$ Porifera, PROTO $=$ Protozoa RHOD = Rhodophyta, SPER $=$ Sper matophyta, TUNIC $=$ Tunicata, VERT $=$ Vertebrata

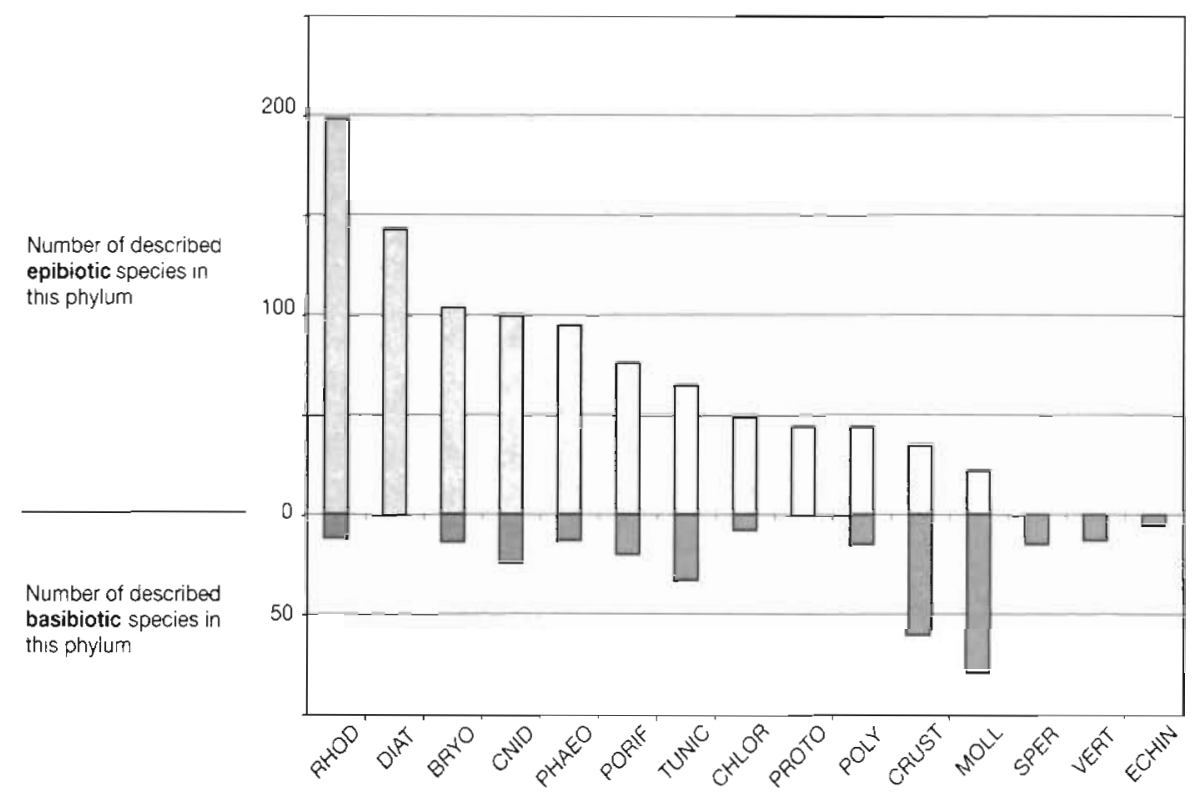

of epibiotic to basibiotic differed between phyla (Fig. 2). For algal phyla, Protozoa, Bryozod, Cnidaria, Porifera, Polychaeta and Tunicata, more epibiotic than basibiotic species have been described. The reverse is true for Crustacea, Mollusca, Echinodermata, Vertebrata and Spermatophyta. In any phylum a given species may play both ecological roles, if in nature it can be found either as substrate organism or as fouling organism, or if it figures as epibiont and basibiont simultaneously in an epibiotic association of the second or a higher order (Wahl 1989).

The most common traits exhibited by epibiotic metazoans were encrusting growth (58\% of described species), facultative or obligate asexual reproduction $(89 \%)$ and modularity (87\%). Epiphytic algae usually were either filamentous or encrusting, and all epibiotic unicellulars are small and capable of asexual reproduction.

'Typical' basibionts live longer than 3 mo (98\%), belong to the epibenthic community, i.e. they do not borrow or swim (90\%), possess physiologically inactive body surface areas like carapaces or shells (83\%), are relatively large in comparison to colonisers $(>5 \mathrm{~cm}$. $95 \%$ ), and are sessile or slow moving (96\%).

In accordance with the foregoing, the small and short-lived diatoms and protozoa almost exclusively featured as epibionts (although they may be fouled by bacteria and eucaryotic unicellulars), while no epibiotic species are described from the phyla Echinodermata, Vertebrata and Spermatophyta, which are either mobile or rooting. In the intermediate series from Rhodophyta over Bryozoa, Phaeophyta, Chlorophyta, Cnidaria, Porifera, Polychaeta, Tunicata, Crustacea to Mollusca, the predominance of epibiotic species grad- ually shifts towards a predominance of basibiotic species. In parallel, across this series of phyla certain life history traits seem to move from more epibiont-like to more basibiont-like: tough, metabolically inactive body surfaces become more common, modularity becomes rarer, individual longevity and weight tend to increase, etc.

Among the 300 personally investigated associations, more than $75 \%$ of the epibiont species occurred on different basibiont species and/or also on artificial or mineral substrata. Basibiont taxa, on average, exhibit between 1.6 (Porifera, median $=1$ ) and 50 (seagrasses, median $=9$ ) epibiont species per basibiont species (Fig. 3).

Consequently, most epibiont species are found on diverse substrata, and the great majority of basibiont species bear more than 1 epibiont species.

\section{DISCUSSION}

\section{Recruitment preferences}

The planktonic pool of colonisers seemed to be homogeneously distributed within the experimental area. All species settled in all microhabitats. Only the red filamentous alga Ceramium rubrum could not be found on any substratum in the Laminaria patch. Artificial substrata were generally preferred over nearby living surfaces. No species was restricted to any particular substratum type, whether living or artificial. Consequently, the coloniser species found in this study may be regarded as facultative epibionts. For the majority of species, the thalli and seagrass tissue ap- 


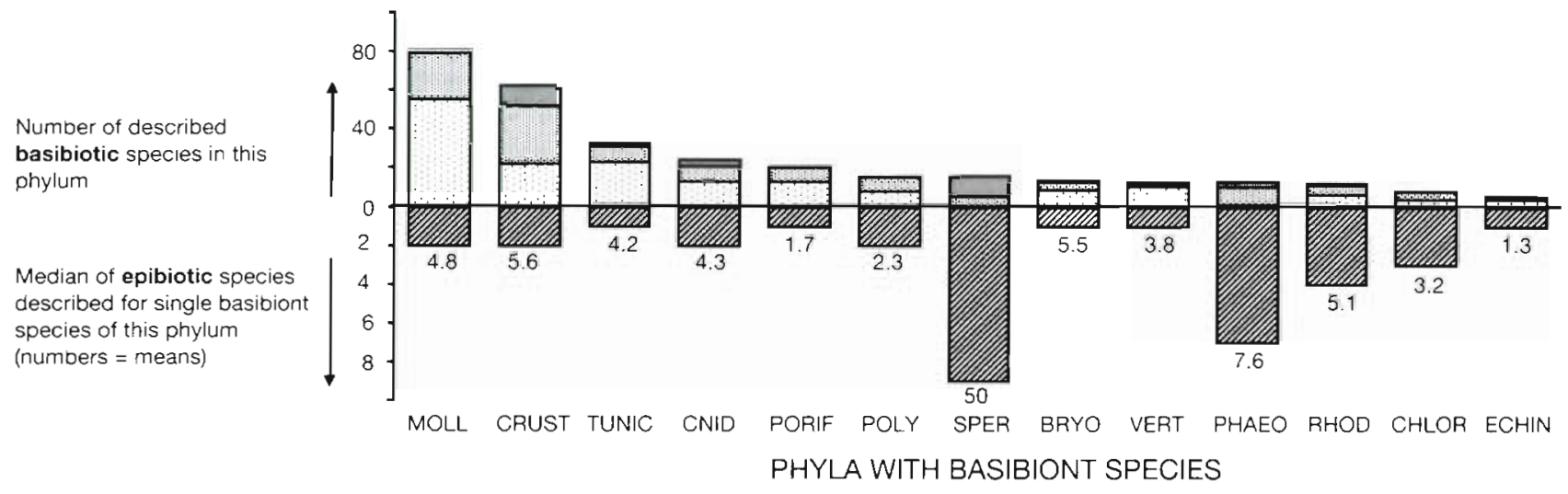

Fig. 3. Specificity of epibiosis. Shadings of upper columns: numbers of basibiont species with 1 (目), 2 to 10 (团) and >10 ( $\square$ ) epibiont species described. Lower columns : median (numbers = mean) of epibiotic species described per basibiont species in a given phylum. Phyla arranged by decreasing number of basibiont species described

pear to be little suited for settlement. When colonisers, while recruiting on nearby artificial substratum, were persistently missing from living surfaces, an effective repulsion of settlers by these surfaces may be suspected (e.g. Fucus and Laminaria). Conversely, the enhanced recruitment by some ciliates onto Zostera or Delesseria surfaces may reflect their attractiveness with regard to these colonisers.

None of the 9 species tested consistently preferred living substratum over artificial substrata, although they exhibited the characteristics of potential epibionts (see below). Living substratum was preferred occasionally by $2(22 \%)$ of the species, whereas all significant preferences of $6(67 \%)$ of the species were in favour of artificial substratum. (One species, Ceramium, did not exhibit significant preferences.) Not a single species settled on only 1 type of surface, i.e. was substratum-specific.

This is consistent with the analysis of over 2000 observed epibiotic associations (see supplementary Internet file). This list, even with regard to the species appearing there, is anything but complete. It may be biassed in other aspects, too: the usual focus of interest was the basibiont, and seagrass epibionts are certainly overrepresented. However, this list is the most comprehensive one available, and many biases are probably moderated by the fact that its contents stem from a wide variety of sources: over 100 biologists working on different questions in different oceans.

Over $75 \%$ of epibiotic species were observed on more than 1 substratum, and the vast majority of basibionts carried more than 1 epibiotic species. This, probably, is an understatement, because the list mainly consists of circumstantial observations and all systematic surveys invariably inventoried the spectrum of epibiotic species on a given basibiont, never the reverse, i.e. basibiont species colonised by a given epibiont.
On the other hand, apparently obligate and sometimes species-specific epibionts have been reported among bacteria (Sar \& Rosenberg 1987, Gil-Turnes et al. 1989, Johnson et al. 1991), Protozoa (Chiavelli et al. 1993), Rhodophyta (Harlin 1980, Lining \& Garbary 1992), Bryozoa (Durante \& Chia 1991), Kamptozoa (Cori 1936, Dyrynda 1985), and Cirripedia (Rajaguru \& Shanta 1992), for instance. In general, however, the great majority of epibiotic species may also be found in the local fouling community on non-living substrata (e.g. Harlin 1980, Cattaneo 1983, D'Antonio 1985, Horner 1987, Otero-Schmitt \& Sanjuan 1992, Gaiser \& Bachmann 1993). The present study, both in its experimental part and in its analysis of observational data, strongly supports the view that most species found attached to living surfaces are neither species-specific nor obligate epibionts. They may colonise other basibiont species and/or non-living surfaces as well or even preferentially so.

The predominantly facultative nature of epibiosis does not imply a complete randomness in epibiotic associations. As illustrated by the frequency distribution of life history characteristics among the epibionts and among the basibionts reported so far, certain sets of features seem to qualify a species better for the one or the other ecological role. Epibionts usually are sessile, small, encrusting or flexible, short-lived, capable of asexual reproduction, and trophically independent of their substratum. Basibionts typically are slow-moving or sessile, non-burrowing, long-lived, large and, often, with part of the outer body surface biologically inactive (with regard to filtration, osmoregulation, etc.). Obviously, body size and longevity are defined relative to the epibiotic or basibiotic partner. Epibiotic traits enable colonisers to reach maturity in face of frequently rather specific conditions at the basibiont's surface (Davis et al. 1989, Wahl 1989). Basibiont traits 
permit toleration of colonisation of varying intensity. For a more detailed discussion of these 2 points see Wahl (1997)

The apparent scarcity of obligate or even speciesspecific epibionts is surprising. In most marine habitats, the dispersal stages of thousands of sessile organisms depend on hard substrata to pursue ontogenesis. Fouling pressure often is high, and available free substratum may easily become a limiting resource (e.g. Clare 1996). Any adaptation enabling a species to colonise and develop on living substrata should represent a competitive advantage. Increasing adaptation with regard to relative body size and growth form, timing of settlement, type of attachment, rate of development, tolerance for surface-specific conditions (microstructure, wettability, chemistry, longevity, etc.) should be selected for. Consequently, a specialised epibiont always settling and developing on the same basibiont in a manner tolerable for or even beneficial (e.g. Wahl et al. 1997) to the latter could escape competition for space, especially if the living substratum was little suited to less well-adapted colonizers. Why, then, are there so few specific epibionts?

We suggest 3 possible explanations.

(1) As uncontrolled fouling is deleterious to most potential basibionts, living surfaces frequently are defended. While any single defence may eventually be overcome by certain preadaptations of potential epibionts, most of the completely analysed defence systems are of a multilevel nature (Wahl et al. 1998), composed of different combinations of mechanical, physical, chemical, associational and/or life history defences. A successful epibiont must cope with all of these. Single preadaptations do not ensure settlement and reproduction on such a multiply defended substratum. The simultaneous appearance of all necessary preadaptation in a potential epibiont is highly unlikely. However, the existence of specific epibionts and endoparasitic or endosymbiotic species possibly derived from epibionts (see below) demonstrates that tolerance of complex defence systems is possible. Temporary colonization during phases when certain defences are 'off', or the colonization of weakened or less well-defended individuals or organs could represent transitory steps.

(2) Once strict basibiont-specificity has evolved in an epibiont species, the latter's survival entirely depends on the well-being of the former. Predation, infection, competitive exclusion, or adverse environmental conditions affecting the basibiont population may rob the specific epibiont species locally of the substratum it depends on. The evolutive gain of competition-free substratum would have to be paid for by a substantial increase in risk factors.

(3) Once a specific epibiont has evolved, it is capable of coping with the particular surface conditions on a given basibiont species. This puts it into an evolutionarily favourable position to 'proceed' towards endoparasitism or endosymbiosis. Certain epibiotic bacteria occasionally penetrate into a (weakened?) host and become endoparasites or pathogens (Kelley \& Williams 1992). The ciliate trichodine group comprises closely related epibiotic and endoparasitic forms (Dogiel 1963). Red algae endoparasitic in rhodophyte hosts have long been suspected to derive from epibiotic ancestors (Sturch 1926). Many microscopic brown algae living in the intercellular space of macroalgae are related to epiphytic phaeophyta. The fact that they are (still?) capable of photosynthesis suggests that they may represent an intermediate stage between epiphytism and endoparasitism (A. Peters pers. comm.). The endoparasitic crustacean genus Sacculina is closely related to other fouling and/or epibiotic cirripedia (Dogiel 1963). On the other hand, some taxa which frequently (e.g. Bryozoa) or predominantly (e.g. Kamptozoa) live epibiotically have never produced endoparasitic forms. With regard to endosymbiosis, Zooxanthellae and Zoochlorellae presumably derive from epibiotic forms (Dogiel 1963). Species of the prokaryotic genus Prochloron live epi- and/or endosymbiotically with Porifera and Tunicata, possibly an evolutionary transition from epibiosis to endosymbiosis (e.g. Lewin 1981, Parry 1985).

A transition from a surface-bound to an interior mode of living allows the invader to escape predation, reduces epibiosis-caused surface effects (shading, drag, insulation, etc.) and intensifies the relationship with the host. This may be beneficial for the former epibiont alone (endoparasitism) or for both partners (endosymbiosis). Obviously, not all endoparasitisms or endosymbioses evolutionarily must pass through an epibiotic phase. Many or most such associations are closely linked to the digestive system of the host.

In conclusion, epibionts and basibionts are characterised relative to each other by a typical set of life history traits. Epibiosis has a predominantly facultative nature. The scarcity of specific epibioses may be due to the widespread existence of multilevel antifouling defence systems and/or to an evolutionarily fast transition from epibiosis to endoparasitism or endosymbiosis.

\section{LITERATURE CITED}

Barkman JJ (1958) On the ecology of cryptogamic epiphytes Math Nat thesis, Leiden

Benzing DH (1989) The evolution of epiphytism. Ecol Stud 76 : $15-43$

Boudreau B, Bourget E, Simard Y (1990) Benthic invertebrate larvae responses to subtrate characteristics at settlement: shelter preference of the American lobster Homarus americanus. Mar Biol 106:191-198

Bruteig IE (1994) Distribution, ecology and biomonitoring studies of epiphytic lichens on conifers. Gunneria 68:1-24 
Cattaneo A. (1983) Grazing on epiphytes. Limnol Oceanogr 28:124-132

Chiavelli DA, Nills EL, Threlkeld ST (1993) Host preference, seasonality, and community inter actions of zooplankton epibionts. Limnol Oceanogr 38(3):574-583

Clare AS (1996) Marine natural product antifoulants: status and potential. Biofouling 9(3):211-292

Cori CI (1936) Kamptozoa. In: Brouns HG (ed) Klassen und Ordnungen des Tierreiches, Band 4(II,4). Akad Verlagsges, Leipzig

D'Antonio C (1985) Epiphytes on the rocky intertidal red alga Rhodomela larix (Turner) C. Agardh: negative effects on the host and food for herbivores? J Exp Mar Biol Ecol 86:197-218

Davis AR, Targett NM, Mcconnell OJ, Young CM (1989) Epibiosis of marine algae and benthic invertebrates: natural products chemistry and other mechanisms inhibiting settlement and overgrowth. In: Scheuer PJ (ed) Bioorganic marine chemistry, Vol 3. Springer Verlag, Berlin, p 86-114

Dogiel VA (1963) Allgemeine Parasitologie. Parasitol Schriftenr $16: 1-523$

Durante KM, Chia FS (1991) Epiphytism on Agarum fimbriatum: can herbivore preferences explain distribution of epiphytic bryozoans? Mar Ecol Prog Ser 77:279-287

Dyrynda PEJ (1985) Chemical defenses and the structure of subtidal epibenthic communities. In: Gibbs PE (ed) Adaptive aspects of physiological and biochemical variability. Proc 19th Eur Mar Biol Symp, Plymouth, 16-21 September 1984. Cambridge Univ Press, London, p 411-424

Gaiser EE, Bachmann RW (1993) The ecology and taxonomy of epizoic diatoms on Cladocera. Limnol Oceanogr 38(3): $628-637$

Gil-Turnes MS, Hay ME, Fenical W (1989) Symbiotic marine bacteria chemically defend crustacean embryos from a pathogenic fungus. Science 246:116-118

Harlin MM (1980) Seagrass epiphytes. In: Phillips RC, McRoy CP (eds) Handbook of seagrass biology: an ecosystem perspective. Jarland STPM Press, New York, p 117-151

Henschel JR, Cook PA (1990) The development of a marine fouling community in relation to the primary film of microorganisms. Biofouling 2:1-11

Horner SMJ (1987) Similarity of epiphyte biomass distribution on Posidonia and artificial seagrass leaves. Aquat Bot 27: $159-167$

Hurlbert SH (1984) Pseudoreplication and the design of ecological field experiments. Ecol Monogr 54(2):187-211

Johnson CR, Muir DG, Reysenbach AL (1991) Characteristic bacteria associated with surfaces of coralline algae: a hypothesis for bacterial induction of marine invertebrate larvae. Mar Ecol Prog Ser 74:281-294

Kelley JI, Williams HN (1992) Bdellovibrios in Callinectes sapidus, the blue crab. Appl Environ Microbio1 58(4):1408-1410

Editorial responsibility: Otto Kinne (Editor),

Oldendorf/Luhe, Germany
Kjelleberg SK, Holmstrom C (1994) Antifoulants from bacteria. In: Kjelleberg S, Steinberg P (eds) Biofouling: problems and solutions. Univ New South Wales, Sydney, p 65-69

Kress WJ (1989) The systematic distribution of vascular epiphytes. Ecol Stud 76:234-270

Laudien J, Wahl M (1999) Indirect effects of epibiosis on host mortality: starfish predation on differently fouled mussels. PSZN I; Mar Ecol 20(1):35-47

Lewin RA (1981) Prochloron and the theory of symbiogenesis. Ann NY Acad Sci 361:325-329

Lining T, Garbary DJ (1992) The Ascophyllum/Polysiphonia/ Mycospaerella symbiosis. Bot Mar 35:341-349

Luettge U (1989) Vascular epiphytes: setting the scene. Ecol Stud $76: 1-14$

Morse ANC (1992) Role of algae in the recruitment of marine invertebrate larvae. In: John DM, Hawkins SJ, Price JH (eds) Plant-animal interactions in the marine benthos. Syst Assoc Spec, Vol 46. Clarendon Press, Oxford, p 385-403

Otero-Schmitt J, Sanjuan A (1992) Epibiotic seaweeds of the Cape Verde Islands. Bot Mar 35(5):379-390

Parry DL (1985) Nitrogen assimilation in the symblotic marine algae Prochloron spp. Mar Biol 87:219-222

Pawlik JR, Butman CA (1993) Settlement of a marine tubeworm as a function of current velocity: interacting effects of hydrodynamics and behaviour. Limnol Oceanogr 38(8): $1730-1740$

Rajaguru A, Shanta G (1992) Association between the sessile barnacle Xenobalanus globicipites (Coronulidae) and the bottlenose dolphin Torsiops truncatus (Delphinidae) from the Bay of Bengal, India, with a summary of previous records from cetaceans. Fish Bull 90:197-202

Roberts D, Rittschof D, Holm E, Schmidt RA (1991) Factors influencing initial larval settlement: temporal, spatial, and surface molecular components. J Exp Mar Biol Ecol 150 . $203-211$

Sar N, Rosenberg E (1987) Fish skin bacteria: colonial and cellular hydrophobicity. Microb Ecol 13:193-202

Sturch HH (1926) Chorecolax polysiphoniae (Reinsch.) Ann Bot (Lond) 40:585-605

Wahl M (1989) Marine epibiosis. I. Fouling and antifouling: some basic aspects. Mar Ecol Prog Ser 58:175-189

Wahl M (1997) Living attached: aufwuchs, fouling, epibiosis. In: Nagabhushanam R, Thompson MF (eds) Fouling organisms of the Indian Ocean: biology and control technology. Oxford \& IBH Publ Co Put Ltd, New Delhi, p 31-83

Wahl M, Hay ME (1995) Associational resistance and shared doom: effects of epibiosis on herbivory. Oecologia 102: 329-340

Wahl M, Hay ME, Enderlein P (1997) Effects of epibiosis on consumer-prey interactions. Hydrobiologia 355:49-59

Wahl M, Kröger K, Lenz M (1998) Non-toxic protection against epibiosis. Biofouling 12(1-3):205-226

Submitted: November 18, 1998; Accepted: March 19, 1999

Proofs received from author(s): September 17, 1999 